\title{
Effectuating Evidence-based Transformative Pedagogical Approaches in STEM Foundational Courses-A Pilot Study
}

\section{Dr. Xiang(Susie) Zhao, Alabama A\&M University}

Dr. Xiang (Susie) Zhao, Associate Professor in the Department of Electrical Engineering and Computer Science at the Alabama A\&M University, has over 15 years of teaching experience in traditional oncampus settings or online format at several universities in US and aboard. Her teaching and research interests include numerical modeling \& simulation, high performance algorithm design, and evidencebased STEM teaching pedagogies. Her recent research work has been funded by DOE, NRC, NASA and NSF, and generated over 40 journal and conference papers. Dr. Zhao also serves as the Principle Investigator of AAMU's NSF WIDER grant-"Effectuating Evidence-based Transformative Pedagogical Approaches in STEM Foundational Courses at AAMU".

\section{Dr. Fayequa Majid, Alabama A\&M University}

Fayeuqa Majid received her Ph.D. in Physics from University of Alabama. She has over twenty years of teaching and research experience. Currently, she is a full professor and Coordinator of Mathematics program at Alabama A\&M University. Her current research is primarily in the area of solitons. She is also involved in research for improving undergraduate STEM education. Currently, she is Co-PI of NSF WIDER grant.

Dr. V. Trent Montgomery, Alabama A\&M University

Dr. Chance M Glenn Sr., Alabama A\&M University

Chance Glenn received his Bachelor's of Science degree in Electrical Engineering from the University of Maryland at College Park. He then received his Master's of Science degree and Doctor of Philosophy degree, both in Electrical Engineering, from The Johns Hopkins University Whiting School of Engineering. He also holds a certificate from the Management Development Program in the Graduate School of Education at Harvard University.

In August of 2012 Dr. Glenn became the Dean of the College of Engineering, Technology, and Physical Sciences at the Alabama A\&M University in Huntsville, Alabama. Dr. Glenn returned to Huntsville after starting school at Alabama A\&M years ago. He is now leading the college through its expansion to prepare students and researchers to meet the global needs of the 21 st century. Dr. Glenn is also the President and Executive Director of the newly formed Alabama A\&M Research, Innovation, Science and Engineering (AAMU-RISE) Foundation. The Foundation's mission is to create new opportunities for the region in research and development. Prior to coming to A\&M he was the Associate Dean of Graduate Studies at the Rochester Institute of Technology in Rochester, New York. He holds several patents and is internationally recognized for research in rf communications and digital signal processing.

\section{Dr. Juarine Stewart, Alabama A\&M University}

Associate Vice President for Academic Affairs and Undergraduate Studies, Director, Centers for Excellence in Teaching and Learning 


\title{
Effectuating Evidence-based Transformative Pedagogical Approaches in STEM Foundational Courses-A Pilot Study
}

\begin{abstract}
A critical juncture in the undergraduate STEM education pathway is the first two years of college when the majority of attrition occurs because students experience many academic challenges in gatekeeping courses. Among many factors to this failure, an important one is attributed to the lack of engaging pedagogy inside and outside classrooms. Through this NSF WIDER Program sponsored planning project, a team of faculty and administrators at Alabama Agricultural and Mechanical University (AAMU) are implementing evidence-based instructional practices in foundation courses in STEM curricula. Recognizing that it is essential to implement effective pedagogy in gateway courses where most attrition occurs, this project has conducted a pilot study, which focuses on: (1) collecting baseline data about the extent to which evidencebased practices are currently being used in STEM gateway courses; (2) redesigning three foundational gateway courses in electrical engineering, computer science and mathematics by applying evidence-based teaching strategies - student-centered problem-based teaching(SCPBT), example-based teaching, and just-in-time teaching (JITT); (3) incorporating classroom and laboratory activities that require active student engagement, conceptual understanding, critical thinking, and problem-solving; and (4) Employing model students to lead Supplementary Instruction (SI) courses with evidence-based peer-to-peer learning strategies. The student assessment data indicated the effectiveness of the evidence-based instructional practices, the SI peer-to-peer learning strategies, as well as existing engagement challenges. In addition, positive feedback was obtained from the student survey data on the redesigned courses. The broader impact of this project is twofold. First, data generated through assessment and evaluation is expected to support the theoretical rationale that systematic change in STEM education must include a wide spectrum of stakeholders (administrators, faculty, staff, and students). Secondly, dissemination of the results of this work is expected to provide a model for institutional implementation of evidence-based practices at colleges or universities of similar size and/or student body demographics as AAMU, a land-granted minority serving university.
\end{abstract}

\section{Introduction}

STEM education is the gateway to prosperity for our ever-evolving technology-dependent society in the $21^{\text {st }}$ century. To succeed in an increasingly integrated global, innovative-driven, and "labor-polarized" economy, the future prosperity of the U.S. depends in large measure on further development of STEM education, research, innovation, and entrepreneurship. During the next decade, "U.S. demand for scientists and engineers is expected to increase at four times the rate for all other occupations" "1]. Yet, only 32\% of undergraduates in the U.S. receive their degrees in STEM while the corresponding figures for Japan, China, and Germany are 55\%, 59\%, 
and $36 \%$, respectively ${ }^{[2]}$. The United States ranks $30^{\text {th }}$ in graduating science and engineering majors as a percentage of the total number of new degrees. China, South Korea, Sweden and Germany (ranked 1-4 respectively) outperformed the United States by more than a factor of 2. According to a report published by the Higher Education Research Institute in January 2010, while the parity gap between White and Asian students and their underrepresented racial minority (URM) peers inspired to be STEM majors has been closed, the degree completion rates still show a wide disparity between these groups ${ }^{[3]}$. The same report states while "approximately $33 \%$ of White and $42 \%$ of Asian Americans completed their bachelor's degree in STEM within five years of college entry, STEM completion rates for Latino, Black, and Native American students were $22.1 \%, 18.4 \%$, and $18.8 \%$ respectively" ${ }^{[4]}$. In 2007, underrepresented minorities comprised $33.2 \%$ of the U.S. college age population, $26.2 \%$ of undergraduate enrollment, and $17.7 \%$ of those earning science and engineering (S\&E) bachelor's degrees. In graduate school, underrepresented minorities comprise 17.7 percent of overall enrollment but are awarded just $14.6 \%$ of S\&E master's and $5.4 \%$ of S\&E doctorate degrees, with a progressive loss of representation as one proceeds up the academic ladder ${ }^{[5]}$.

Researchers offer many explanations for the persistent achievement gaps while recognizing that there are many interrelated factors. They agree that family and community differences, school context, low expectations, and lack of exposure to role models, information about career opportunities, and advanced courses affect minority students' success in mathematics and science. "To succeed in today's information-based and highly technological society, all students need to develop their capabilities in STEM to levels much beyond what was considered acceptable in the past" ${ }^{[6]}$. STEM education must provide emerging scientists and engineers with innovative talents to energize the economic engines of the future.

A critical juncture in the undergraduate STEM education pathway is the first two years of college when the majority of attrition occurs because students experience many academic challenges in gatekeeping courses ${ }^{[7]}$. An important factor to this failure is attributed to the lack of engaging pedagogy. Research has shown that many prospective college students drop out of college for various reasons, such as academic unpreparedness, financial constraints, lack of guidance from mentors, educational burnout, wrong academic major, and excessive external demands from part-time employment needed for financial support through college. Less than $40 \%$ of students enrolled in various STEM disciplines complete their degree ${ }^{[8]}$.

The ingredients for success in STEM disciplines are the acquisition of knowledge and habits of mind; opportunities to put these into practice; a developing sense of competence and progress; motivation to be in, a sense of belonging to, or self-identification with the field; and information about stages, requirements, and opportunities. Under the support of National Science Foundation (NSF), this project aims to improve the active learning and engagement of the students in their STEM foundational course, thereby pave the pathway for students to move toward their success in the future studies and careers. The rest of the paper is structured as follows: Section 2 provides a brief introduction to the evidence-based teaching pedagogical methodologies that have been utilized in this project. Section 3 describes the implementation approaches followed by the experimental results and discussion in Section 4. Section 5 presents the conclusions and future directions. 


\section{Review of evidence-based teaching methodologies}

Teaching is an art of encouraging students to become active learners and awakening their enthusiasm to life-long learning. We believe that by acquiring knowledge regarding modern methodologies, metacognition, and learning styles, one can master this art. Learning is a dynamic process in which both the teacher and students actively participate, exchange views, and ask/answer questions in an engaging atmosphere ${ }^{[9]}$. It has been abundantly demonstrated that pedagogical methods that promote conceptual understanding through interactive engagement of students are far more effective than traditional didactic instructional methods. Almost all of the newly developed methods on teaching and learning have concentrated on student-centered, inquiry-based approaches ${ }^{[10]}$. These techniques are especially effective when structured in ways that address the preconceptions that STEM students bring to the classroom. Some strategies, such as Modeling Methods ${ }^{[11]}$ and Just-in-Time-Teaching ${ }^{[12]}$ have shown significant success and others, such as Process-Oriented Guided Inquiry Learning (POGIL) ${ }^{[13]}$, Problem-Based Learning (PBL) ${ }^{[14]}$, and Game-Based Learning (GBL) ${ }^{[15]}$ have gained more prominence and national recognition. Yet others, such as Competency Performance Recordings for Learning $(\mathrm{CPRL})^{[16]}$, Reciprocal Peer Tutoring (RPT) ${ }^{[17]}$, Socratic Dialogue Inducing (SDI) ${ }^{[18]}$, and Investigative Science Learning Environment ${ }^{[19]}$ are innovative and empirically supported pedagogies.

One of the successful evidence-based designs for teaching science and engineering courses is the Problem-Based Learning (PBL). The earliest successful adoption of PBL is in medical education [20][21], but PBL was quickly infused into other STEM disciplines. PBL is a pedagogical model in which students are the center of the learning process. Students become the active learner who connect domain knowledge to real-world challenging problems, and work collaboratively toward their solutions. The instructor provides resources and mentorship to students on how to tackle the problem, not the solution directly. The major advantages of PBL include deepening students' critical thinking, stimulating students' interests in their areas of study, motivating students' problem solving and therefore engagement ${ }^{[22]}{ }^{[23][24]}$. However, the challenges do exist for the academically under-prepared student groups or when lack of appropriate tutor resources ${ }^{[25][26]}$.

Just in Time Teaching (JiTT) is a pedagogical strategy developed to allow instructors to adapt their lectures to specific student learning difficulties so that the instructor can fine tune the classroom activities to best meet students' needs. The students give their immediate feedback online to their learning difficulties after each class meeting. The key advantage of JiTT is the rapid feedback that gives the instructor an idea of how to adjust the lectures in terms of understanding the concepts and their work to be done accordingly for the learning by use of information technology to enhance learning ${ }^{[27]}$.

\section{Our Approaches}

Through this NSF WIDER Program sponsored planning project, a team of faculty and administrators at Alabama Agricultural and Mechanical University (AAMU) are implementing 
evidence-based instructional practices in foundation courses in STEM curricula. Recognizing that it is essential to implement effective pedagogy in gateway courses where most attrition occurs, this project has conducted a pilot study, which focuses on: (1) collecting baseline data about the extent to which evidence-based practices are currently being used in STEM gateway courses; (2) redesigning three foundational gateway courses in electrical engineering, computer science and mathematics by applying evidence-based teaching strategies - student-centered problem-based teaching(SC-PBT), example-based teaching, and just-in-time teaching (JITT); (3) incorporating classroom and laboratory activities that require active student engagement, conceptual understanding, critical thinking, and problem-solving; and (4) Employing model students to lead Supplementary Instruction (SI) courses with evidence-based peer-to-peer learning strategies. This section mainly describes the details on the implementation of evidencebased teaching and SI program in selected STEM gateway courses.

\subsection{Implementing evidence-based teaching in STEM gateway courses}

Innovative, evidence-based instructional practices are critical to transforming the conventional undergraduate instructional landscape into a student-centered learning environment. Approaches that are considered particularly promising for accomplishing this include enhanced facultystudent interaction; enhanced peer interaction; more opportunities for personalized learning; opportunities to receive and communicate information across diverse modalities; greater attention to problem-solving and conceptual understanding; and more technology-enhanced, web-facilitated instructions. This project is a synergistic effort that includes university-level administrators, Dean and Chairs, along with faculty members serving students majoring in STEM disciplines. The project seeks transformational change and quality improvement in instructional practices driven from research concerning effective STEM pedagogy that typically incorporates classroom or laboratory activities that require active student engagement, conceptual understanding, critical thinking, and problem solving. In fall 2014, three foundational, gateway courses were selected in STEM disciplines to integrate the evidence based teaching as the pilot study: CS102-"Introduction to Programming I", EE204-"Digital Logic Design and Analysis", and MTH125-"Calculus I". Comparative study were conducted on the same courses (taught by the same instructors) between spring 2014 and fall 2014. Figure 1 shows the implementation/assessment framework that has been established and applied to the STEM courses in this pilot study. All stakeholders including administrators, faculty, staff, and students have been involved in this framework.

Firstly, the student learning outcomes for each course was set as the same as in spring 2014 for the purpose of comparison and the obligation of the program accreditation. Secondly, a student entry survey was conducted to gather students' info on their high school preparation in STEM areas, study habits, the accessibility of the learning tools and technology, off-campus jobs, etc.

Thirdly, the selected courses were redesigned to integrate various evidence-based teaching pedagogical approaches. The student entry survey showed that a significant portion of the students were academically underprepared. So a hybrid student-centered PBL (SC-PLB) was implemented in CS102 and EE204, which increased the amount of instructor's lecture time at the beginning to help students get sufficient pre-requisite knowledge and skills before they can start the relatively independent problem-solving. Problems sets and laboratory materials were also 
designed surrounding the outcomes in CS102 and EE204. MTH125 has been identified as one of the most challenging gateway courses that require lots of instructor's intervention and explanation. So the Just-in-Time Teaching (JiTT) was chosen instead of PLB. JiTT was implemented to include group teaching and learning in class and assigned work of these groups online using blackboard technology. Student groups responded online with difficulties they faced in class lecture and to their assignments. They also responded to their difficulties after receiving quizzes and tests as well. Based on these responses, quizzes and tests were reviewed in class.

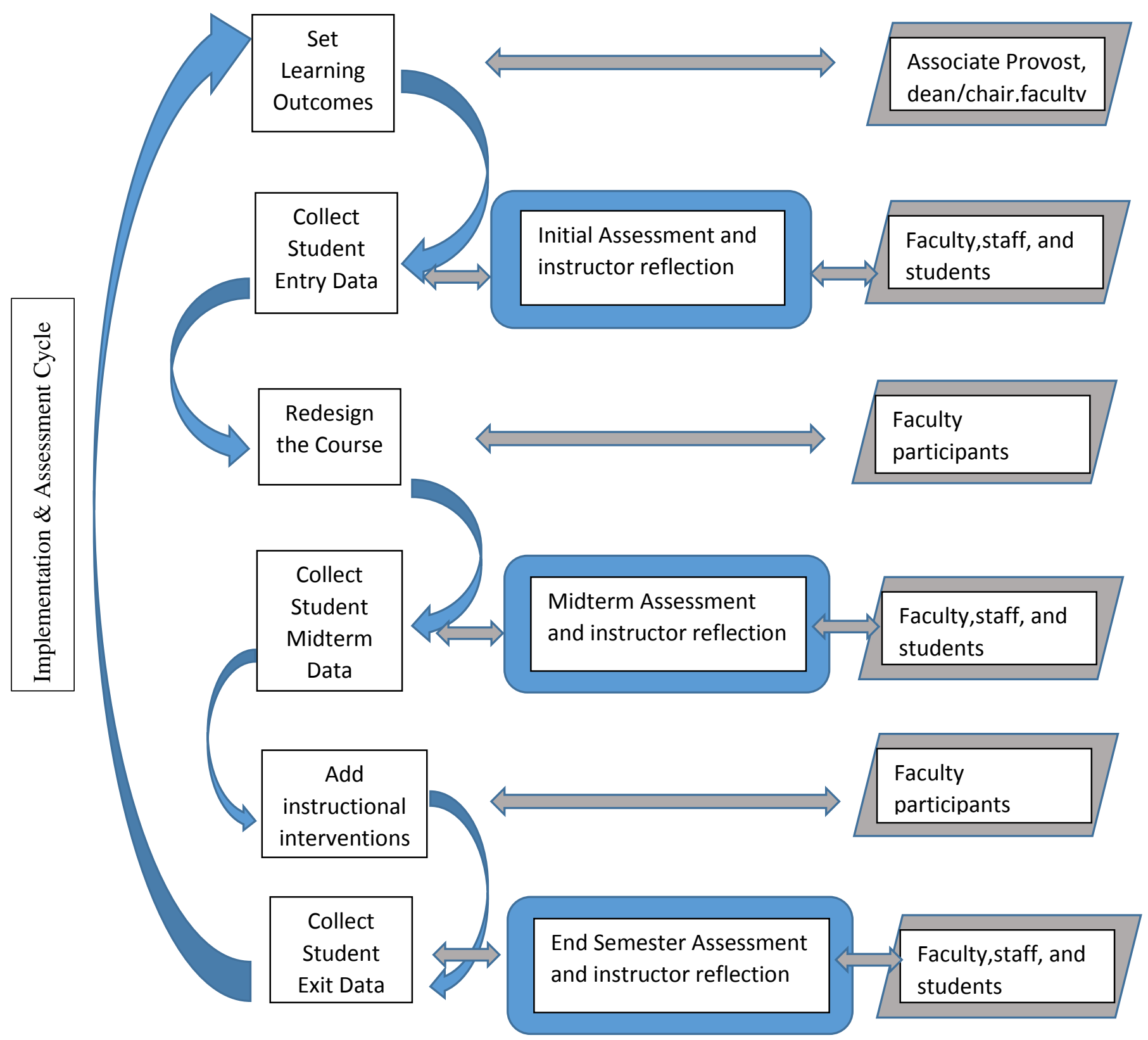

Figure 1. The implementation and assessment framework 
Fourthly, the midterm survey and exam were conducted for each other to get the students' feedback on the adopted new teaching strategies, followed by an immediate adjustment of the instructor's intervention as needed in the fifth step. For example, from the midterm survey and exam, students in CS102 demonstrated weaker understanding on some concepts and skills such as using variables and arithmetic expressions. The instructor added example-based learning and in-class lab times to accommodate this needs. Lastly, the exit survey and final exam were conducted to evaluate and assess the outcomes of the adopted teaching strategies. The experimental results are presented in Section 4.

\subsection{Integrating Supplementary Instruction (SI) in STEM gateway courses}

The basic premise of our retention effort is a focused, institution-wide effort rather than fragmented (departmental) and/or diffused initiatives. Attrition is a multi-variant phenomenon that requires improving students' life and learning experiences. An extensive body of research identifies several mechanisms to promote students to persist and graduate. Promoting retention in a college setting is attributed to (i) effective and personalized advising; (ii) a social and academic supportive environment; and (iii) an atmosphere that fosters collaborative and cooperative teaching and learning. Our retention activities are facilitated through STEM Supplemental Instruction (SI) program.

Over the past four years, the significant results of AAMU's SI program with dramatic drops in underachievement being replaced by higher levels of success in gateway courses has shown that students are persisting in their majors. In SI sessions, emphasis has been placed on problem solving, active learning, and efforts to promote students' motivation, critical and complex thinking to ensure their deep understanding of content knowledge [28],[29]. The past results indicate that the SI strategy is effective in enhancing student performance in introductory STEM courses.

Building upon the success of our existing SI program, model students are chosen to be peer tutors (also called as SI leaders), based on their academic achievement in the identified courses, using GPA as the criterion. Potential SI leaders are required to submit an application and two letters of recommendation. Once selected, the SI leaders need to participate in the training workshop before all classes start. SI assistance begins at the beginning of the course. During the first class session, the SI leader describes SI and surveys the class to establish a schedule for the SI leader to conveniently serve interested participants. Each SI leader is required to offer three review sessions every week for students. SI sessions occur in classrooms near the course classroom and sessions are open to all students enrolled in that course. SI sessions are attended on a voluntary basis. SI leaders are paid biweekly from the project grant.

\section{Results and discussion}

This section summarizes the experimental results obtained from this pilot study conducted in fall 2014. A comparative study was also accomplished to verify the effectiveness of the methodologies. 


\subsection{Implementation of the evidence-based teaching in STEM gateway courses}

CS102-"Introduction to Programming I" has been chosen as one of the STEM pilot courses because it is the first programming course and also the pre-requisite of many other core course in the computer science curriculum at AAMU. Underperformed students in CS102 are very likely to struggle or fail in other courses afterwards. Therefore, CS 102 has been considered a gateway course in computer science. Table 2 lists the students learning outcomes and corresponding assessment methods. The same eight outcomes were assessed in spring and fall 2014 while the hybrid SC-PBL was implemented in fall 2014 only. EE204 and MTH125 follow the same strategy though the outcomes are not listed here.

Table 1. The learning outcomes of CS102

\begin{tabular}{|l|l|l|}
\hline Topic Areas & Learning Outcome & $\begin{array}{l}\text { Assessment } \\
\text { Method }\end{array}$ \\
\hline $\begin{array}{l}\text { Ch.1. Overview of Programming } \\
\text { and Problem Solving }\end{array}$ & $\begin{array}{l}\text { 1. Understand the concepts of algorithm, } \\
\text { computer program, high-level programming } \\
\text { language, flow charts, and the brief history of } \\
\text { C++. }\end{array}$ & $\begin{array}{l}\text { Homework/ } \\
\text { Tests }\end{array}$ \\
\hline $\begin{array}{l}\text { Ch.1. Overview of Programming } \\
\text { and Problem Solving }\end{array}$ & $\begin{array}{l}\text { 2. Understand the major components of } \\
\text { computers and how they work together. }\end{array}$ & Homework/ \\
\hline $\begin{array}{l}\text { Ch.1. Overview of Programming } \\
\text { and Problem Solving }\end{array}$ & $\begin{array}{l}\text { 3. Be able to enter, edit, compile, link, } \\
\text { troubleshoot and run C++ programs. }\end{array}$ & Homework/ \\
\hline $\begin{array}{l}\text { Ch. 2. C++ Syntax and Semantics, } \\
\text { and the Program Development } \\
\text { Process }\end{array}$ & $\begin{array}{l}\text { 4. Understand the structure of a C++ program } \\
\text { and how to use different types of variables and } \\
\text { constants. }\end{array}$ & Homework/ \\
\hline $\begin{array}{l}\text { Ch.3. Numeric Types, Expressions, } \\
\text { and Output }\end{array}$ & $\begin{array}{l}\text { 5. Understand the arithmetic operators and } \\
\text { how to write and evaluate arithmetic } \\
\text { expressions. }\end{array}$ & $\begin{array}{l}\text { Homework/ } \\
\text { Labs/Tests }\end{array}$ \\
\hline $\begin{array}{l}\text { Ch.3. Numeric Types, Expressions, } \\
\text { and Output } \\
\text { Ch.4. Program Input and the } \\
\text { Software Design Process }\end{array}$ & $\begin{array}{l}\text { finderstand and be able to use standard I/O, } \\
\text { frograms. }\end{array}$ & Homework/ library functions in C++ \\
\hline $\begin{array}{l}\text { Ch.5. Conditions, Logical } \\
\text { write and evaluate logical expressions }\end{array}$ & Labs/Tests \\
\hline
\end{tabular}




\begin{tabular}{|l|l|l|}
\hline Ch.5. Conditions, Logical & $\begin{array}{l}\text { 8. Understand and be able to use basic control } \\
\text { structures (selection and looping) in C++ } \\
\text { Structures }\end{array}$ & Homework/ \\
$\begin{array}{l}\text { Ch.6. Looping } \\
\text { Ch. 9. Additional Control Structures }\end{array}$ & & Labs/Tests \\
& & \\
\hline
\end{tabular}
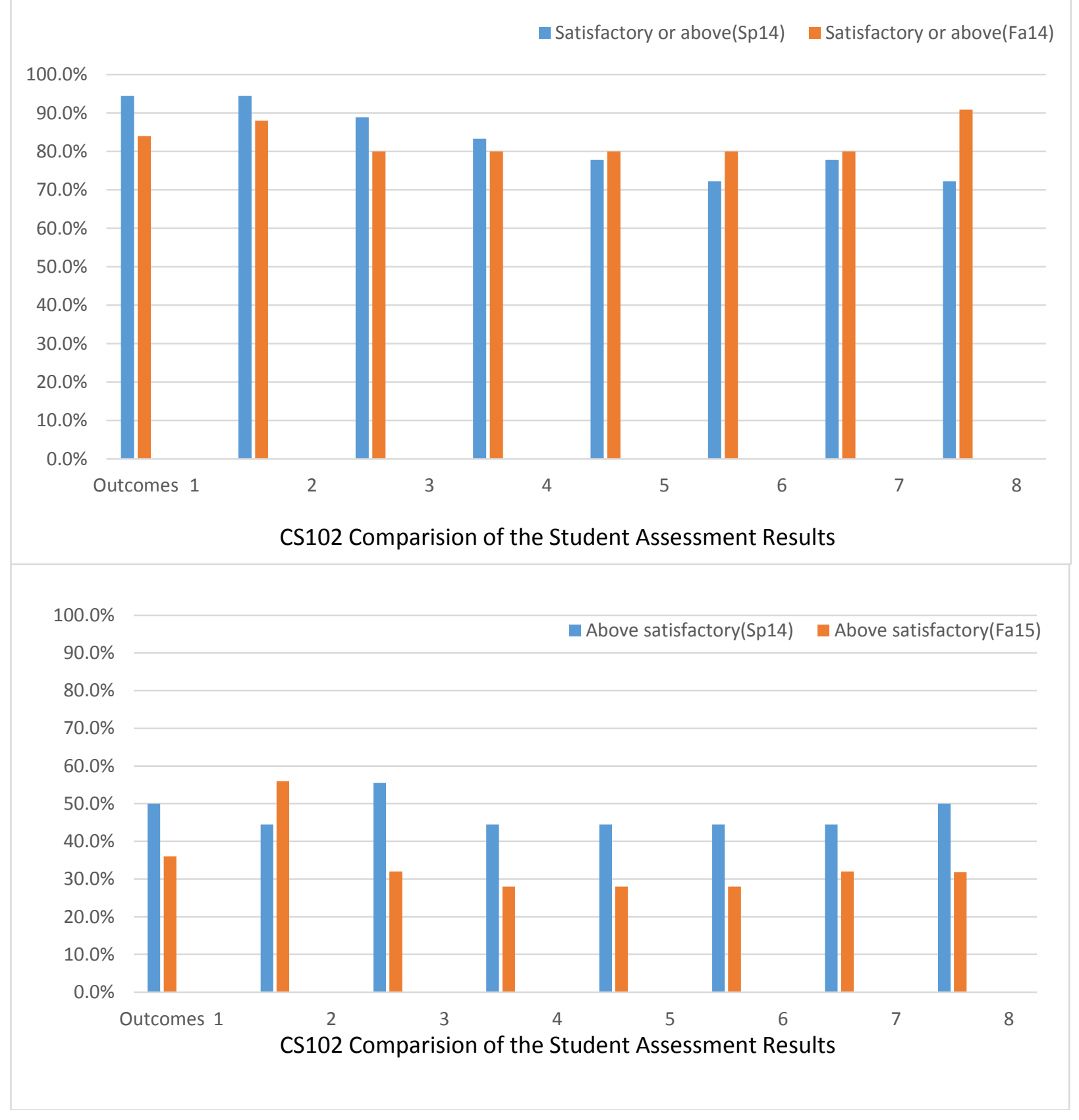

Figure 2. Comparison of the student assessment results between spring 2014 and fall 2014 in CS102 


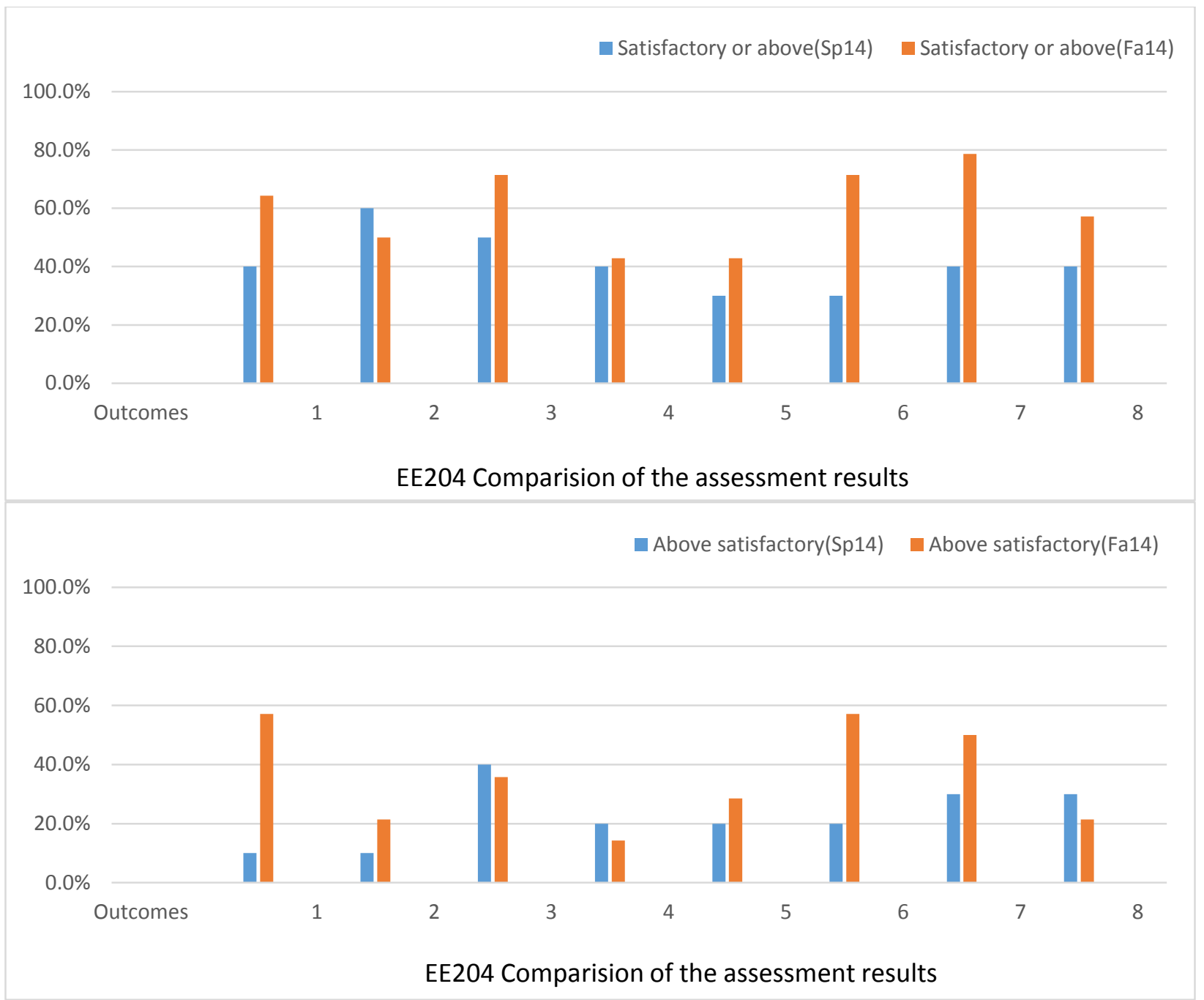

Figure 3. Comparison of the student assessment results between spring 2014 and fall 2014 in EE204

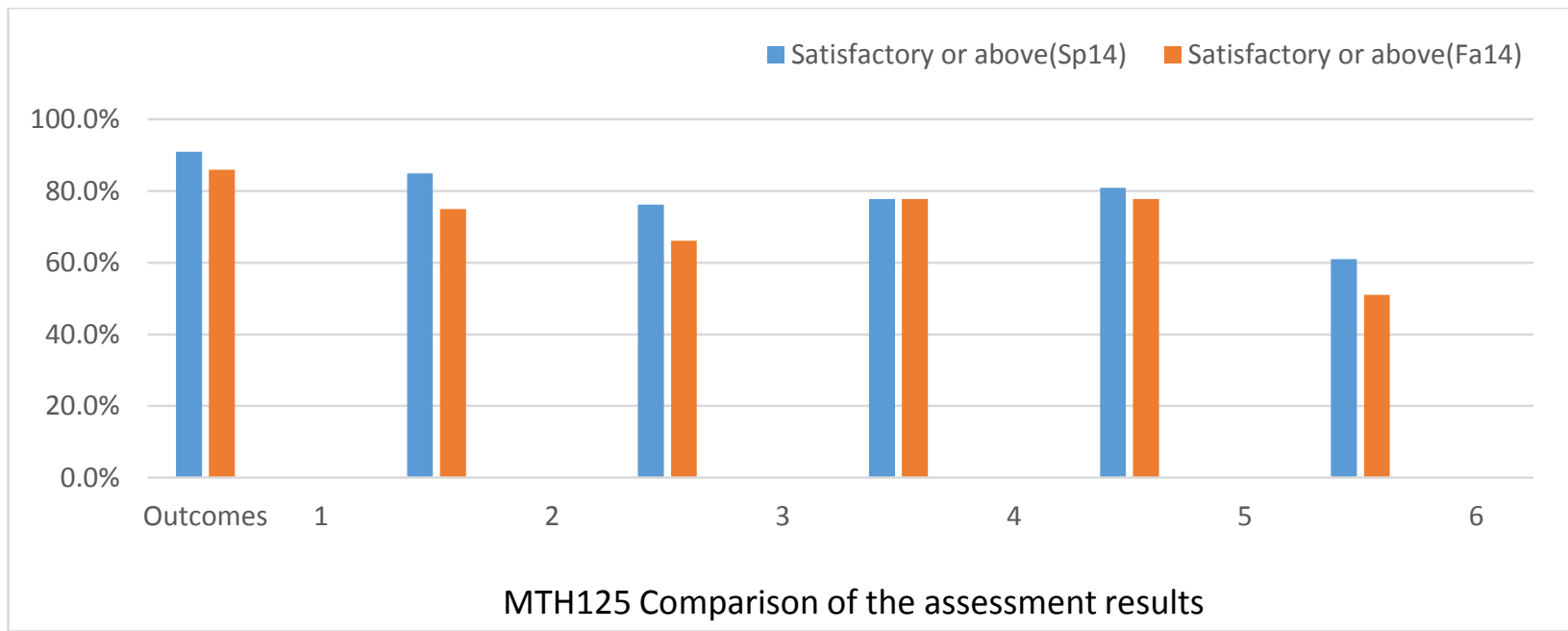

Figure 4. Comparison of the student assessment results between spring 2014 and fall 2014 in MTH125 
Figures 2-4 includes the comparison of the student assessment results upon the same learning outcomes between spring and fall 2014. It has been observed that the percentage of "Satisfactory or above" students was slightly decreased over the first three learning outcomes in CS102. One important factor contributed to this is that majority of the students in CS102 in fall 2014 were first-semester freshmen, who needed longer registration settlement and lab/classroom/dorm acquaintance period. Therefore, those students were not fully ready or engaged at the first a few weeks when the first three outcomes are mainly assessed. It is very promising that after this "start-up" process was over, the students' performance were gradually improved over the last four learning outcomes, although those learning outcomes demand more deep thinking and advanced problem solving skills than the first three outcomes. This verifies the effectiveness of the hybrid SC-PBL methodology on students' learning and engagement. The similar trends are also identified in Figure 3 for EE204. It is also found that the percentage of "Above satisfactory" category was not improved in fall over spring semester for CS102 as showed in Figure 2, but this category was improved in EE204. EE204 is a sophomore level gateway course in electrical engineering program. This raised some caution and challenges to the instructors when PBL is implemented in freshman-level courses: How much guidance and how much self-exploration (problem-solving) time should be given to students? How to stimulate both the strong and weak students?

Challenges were also found in MTH125, in which the JiTT was implemented in fall 2014. Through the interview with the instructor, it has been found that students' feedback needed for JiTT did not get enough responses and in effect, could not be delivered to the instructor as expected due to lack of computer technology and facilities issues such as Blackboard training. A lot of students did not have the Blackboard training and they had no time to get the training due to job issues after classes. Some students did not have computers and they could not use the on campus computer facility for the time constraints. Additionally, financial constraints such as no textbooks, no computers, and living off campus with not enough transportation facilities to arrive on campus on time eventually affected their routine absences from classes as well. As showed in Figure 4, the comparison of spring 2014 with traditional teaching and fall 2014 with JiTT final exams did not show any significant improvement for fall 2014. In fact, fall 2014 result is slightly lower than spring 2014 in many aspects. It could be due to two different student bodies as well as other issues incurred for fall 2014 students as stated above.

In addition to the formal assessment, a student survey has been conducted to provide the evaluation and feedback. The student survey summary in Table. 2 showed the positive feedback on the problem-based learning (PBL) and example-based teaching (EBT) strategies implemented in CS102. For example, 60\% students agreed PBL "improve my critical thinking" in the midterm survey and this number was increased to $73 \%$ at the end of the semester. In addition, majority of the students agreed "I can see how programming is useful to solve read-world problems" through PBL. 40-45\% of students felt PBL "improve my interests to learn new $\mathrm{C}++$ programming skills". It is especially worthy of mentioning that only 20\% students agreed PBL can "improve my self-confidence", but this number was increased to $55 \%$ at the end of the semester. Similarly positive feedback are also obtained from the surveys for EE204 and MTH125. 
Table 2. CS102 Student Survey Summary

\begin{tabular}{|c|c|c|c|}
\hline Student Survey Questions & Survey Answer Choices & $\begin{array}{l}\text { Midterm } \\
\text { Survey } \\
\text { Summary } \\
\end{array}$ & $\begin{array}{l}\text { Exit } \\
\text { Survey } \\
\text { Summary } \\
\end{array}$ \\
\hline \multirow{6}{*}{$\begin{array}{l}\text { How does the problem-based } \\
\text { learning (PBL) the instructor used } \\
\text { in this course benefit you? }\end{array}$} & a) improve my critical thinking & $60 \%$ & $73 \%$ \\
\hline & $\begin{array}{l}\text { b) improve my interests to learn } \\
\text { new C++ programming skills }\end{array}$ & $40 \%$ & $45 \%$ \\
\hline & $\begin{array}{l}\text { c) I can see how programming is } \\
\text { useful to solve read-world } \\
\text { problems }\end{array}$ & $53 \%$ & $45 \%$ \\
\hline & $\begin{array}{l}\text { d) allow me to interact with my } \\
\text { peers and work together }\end{array}$ & $40 \%$ & $55 \%$ \\
\hline & e) improve my self-confidence & $20 \%$ & $55 \%$ \\
\hline & f) no benefit & $20 \%$ & $0 \%$ \\
\hline \multirow{4}{*}{$\begin{array}{l}\text { 2. What is the challenges did you feel } \\
\text { when the instructor used the } \\
\text { problem-based learning (PBL) in } \\
\text { this course? }\end{array}$} & $\begin{array}{l}\text { a) Take more time to figure out } \\
\text { the solution }\end{array}$ & $67 \%$ & $73 \%$ \\
\hline & $\begin{array}{l}\text { b) As freshmen, it is hard to work } \\
\text { on a problem from scratch }\end{array}$ & $20 \%$ & $55 \%$ \\
\hline & c) No much challenge for me & $20 \%$ & $9 \%$ \\
\hline & d) Other & $0 \%$ & $0 \%$ \\
\hline \multirow{5}{*}{$\begin{array}{l}\text { 3. What are your } \\
\text { suggestions/comments you like to } \\
\text { give to help the instructor to } \\
\text { improve the problem-based learning } \\
\text { (PBL) in this course? }\end{array}$} & $\begin{array}{l}\text { a) Give more time to work on the } \\
\text { problem if time is permitted }\end{array}$ & $67 \%$ & $27 \%$ \\
\hline & $\begin{array}{l}\text { b) Allow students to give inputs } \\
\text { on creating new problems }\end{array}$ & $40 \%$ & $45 \%$ \\
\hline & $\begin{array}{l}\text { c) Need extra outside class } \\
\text { review sessions }\end{array}$ & $33 \%$ & $55 \%$ \\
\hline & $\begin{array}{l}\text { d) Give more sample programs in } \\
\text { Blackboard }\end{array}$ & $53 \%$ & $45 \%$ \\
\hline & e) Other & $7 \%$ & $0 \%$ \\
\hline \multirow{6}{*}{$\begin{array}{l}\text { 4. How do you like the problem-based } \\
\text { learning (PBL) the instructor used } \\
\text { in this course? Use } 1-5 \text { to indicate } \\
\text { the level of likeness (from "strongly } \\
\text { dislike" to "strongly like") }\end{array}$} & 1 & $9 \%$ & $0 \%$ \\
\hline & 2 & $11 \%$ & $3 \%$ \\
\hline & 3 & $30 \%$ & $20 \%$ \\
\hline & 4 & $23 \%$ & $37 \%$ \\
\hline & 5 & $27 \%$ & $40 \%$ \\
\hline & a) improve my critical thinking & & $91 \%$ \\
\hline
\end{tabular}




\begin{tabular}{|c|c|c|c|}
\hline \multirow{5}{*}{$\begin{array}{l}\text { 5. How does the example-based } \\
\text { teaching (EBT) the instructor used } \\
\text { in this course benefit you? }\end{array}$} & $\begin{array}{l}\text { b) improve my interests to learn } \\
\text { new } \mathrm{C}++ \text { programming skills }\end{array}$ & \multirow[t]{5}{*}{$\begin{array}{l}\text { Did not } \\
\text { survey }\end{array}$} & $64 \%$ \\
\hline & $\begin{array}{l}\text { c) I can see how other people use } \\
\mathrm{C}++ \text { to solve problems }\end{array}$ & & $55 \%$ \\
\hline & $\begin{array}{l}\text { d) allow me to figure out the } \\
\text { solutions to new problem } \\
\text { easily }\end{array}$ & & $36 \%$ \\
\hline & e) improve my self-confidence & & $45 \%$ \\
\hline & f) no benefit & & $0 \%$ \\
\hline \multirow{5}{*}{$\begin{array}{l}\text { 6. How do you like the example-based } \\
\text { teaching (EBT) the instructor used } \\
\text { in this course? Use 1-5 to indicate } \\
\text { the level of likeness (from "strongly } \\
\text { dislike" to "strongly like") }\end{array}$} & 1 & \multirow{5}{*}{$\begin{array}{l}\text { Did not } \\
\text { survey }\end{array}$} & $0 \%$ \\
\hline & 2 & & $9 \%$ \\
\hline & 3 & & $36 \%$ \\
\hline & 4 & & $18 \%$ \\
\hline & 5 & & $36 \%$ \\
\hline
\end{tabular}

\subsection{SI program summary}

In this project, a pool of approximately 240 students in seven foundational mathematics, chemistry, computer science, and engineering courses were included in SI program in fall 2014. Table 3 presents the results of the SI program.

Table 3. SI Program Summary

\begin{tabular}{|c|c|c|c|c|c|c|c|c|c|c|}
\hline $\begin{array}{c}\text { SEM/Y } \\
\text { R }\end{array}$ & Course & $\begin{array}{c}\text { Grade } \\
\text { d Class } \\
\text { Enroll. }\end{array}$ & $\begin{array}{c}\# \\
\text { Att. }\end{array}$ & $\%$ Att. & $\begin{array}{c}\# \\
\text { Sess } \\
\cdot\end{array}$ & $\begin{array}{c}\# \\
\text { Cont } \\
\text {. Hrs }\end{array}$ & $\begin{array}{c}\# \\
\text { ABC } \\
\text { SI }\end{array}$ & $\begin{array}{c}\% \text { ABC } \\
\text { / SI }\end{array}$ & $\begin{array}{c}\# \\
\text { ABC } \\
\text { Non- } \\
\text { SI }\end{array}$ & $\begin{array}{l}\% \text { ABC } \\
\text { Non-SI }\end{array}$ \\
\hline FA 2014 & $\begin{array}{l}\text { EE 204- } \\
0\end{array}$ & 14 & 9 & $64.29 \%$ & 91 & 20 & 9 & $\begin{array}{r}100.00 \\
\%\end{array}$ & 0 & $0.00 \%$ \\
\hline FA 2014 & $\begin{array}{l}\text { CS 102- } \\
2\end{array}$ & 23 & 9 & $39.13 \%$ & 42 & 17 & 8 & $88.89 \%$ & 4 & $28.57 \%$ \\
\hline FA 2014 & $\begin{array}{l}\text { MTH } \\
125-4\end{array}$ & 31 & 5 & $16.13 \%$ & 42 & 13 & 3 & $60.00 \%$ & 16 & $61.54 \%$ \\
\hline FA 2014 & $\begin{array}{l}\text { MTH } \\
125-2\end{array}$ & 38 & 14 & $36.84 \%$ & 54 & 51 & 4 & $28.57 \%$ & 11 & $45.83 \%$ \\
\hline FA 2014 & $\begin{array}{l}\text { MTH } \\
105-1\end{array}$ & 30 & 2 & $6.67 \%$ & 40 & 2 & 2 & $\begin{array}{r}100.00 \\
\%\end{array}$ & 19 & $67.86 \%$ \\
\hline FA 2014 & $\begin{array}{l}\text { CHE } \\
101-1 \\
\end{array}$ & 52 & 20 & $38.46 \%$ & 39 & 102 & 13 & $65.00 \%$ & 11 & $34.38 \%$ \\
\hline FA 2014 & $\begin{array}{l}\text { CHE } \\
101-2\end{array}$ & 47 & 12 & $25.53 \%$ & 37 & 39 & 10 & $83.33 \%$ & 22 & $62.86 \%$ \\
\hline Total & 7 & 235 & 71 & $32.44 \%$ & 345 & 244 & 49 & $75.11 \%$ & 83 & $43.00 \%$ \\
\hline
\end{tabular}


In fall 2014, total 345 SI study sessions were offered by the four SI leaders with over 70 students participated. SI study results in Table 3 showed students who participated in the SI tutorial program had an average improvement of one letter grade higher than non-participants. On average, the percentage of SI participants receiving an A, B, or C was increased by over $30 \%$ over non-participants in all of the courses that implemented SI. The courses implementing SI also observed a significant reduction in the D, W, and F rates for SI participants as well. Moreover, the feedback from students further confirmed the positive impact of SI program on students' learning outside classrooms. All participates expressed their favor of the SI sessions in their final evaluation.

\subsection{Faculty survey summary}

A faculty survey was conducted in fall 2014 to collect baseline data of faculty's awareness, practice and attitude on evidence-based teaching. 57 faculty with various academic ranks and teaching experiences across total ten STEM disciplines in three colleges at AAMU participated in the survey. Table 4 summarizes the major survey results. The faculty's background and academic status information were in the survey but not included in this table.

Table 4. Faculty Survey Summary

\begin{tabular}{|c|c|}
\hline Some Survey Questions & Summary of the Answers \\
\hline $\begin{array}{l}\text { 1. Are you familiar with any Evidence-Based Teaching (EBT) } \\
\text { pedagogical approach }\end{array}$ & $\begin{array}{l}\text { Yes } 25 \% \\
\text { No } 75 \%\end{array}$ \\
\hline $\begin{array}{l}\text { 2. Have you ever been introduced to any Evidence-Based } \\
\text { Teaching (EBT) pedagogical approach? }\end{array}$ & $\begin{array}{ll}\text { Yes } & 17 \% \\
\text { No } & 83 \%\end{array}$ \\
\hline $\begin{array}{l}\text { 3. Have you ever adopted any Evidence-Based Teaching } \\
\text { (EBT) pedagogical approach in your course? }\end{array}$ & $\begin{array}{ll}\text { Yes } 23 \% \\
\text { No } \quad 77 \%\end{array}$ \\
\hline $\begin{array}{l}\text { 4. Has your program or department promoted any Evidence- } \\
\text { Based Teaching (EBT) pedagogical approach }\end{array}$ & $\begin{array}{l}\text { Yes } 9 \% \\
\text { No } 91 \%\end{array}$ \\
\hline $\begin{array}{l}\text { 5. Are you interested in adopting any new pedagogical } \\
\text { approach such as EBT in your course(s)? }\end{array}$ & $\begin{array}{l}\text { Yes } 91 \% \\
\text { No } 9 \%\end{array}$ \\
\hline $\begin{array}{l}\text { 6. If you answered "yes" to last question, please indicate what } \\
\text { level of course(s) do you plan to apply some new } \\
\text { pedagogical approach? }\end{array}$ & $\begin{array}{l}\text { Freshman } 45 \% \\
\text { Sophomore } 19 \% \\
\text { Junior } 21 \% \\
\text { Senior } 15 \%\end{array}$ \\
\hline $\begin{array}{l}\text { 7. What is your anticipated major concern when you adopt a } \\
\text { new pedagogical approach to your course(s)? }\end{array}$ & $\begin{array}{l}\text { Increased Workload } 64 \% \\
\text { Need of Administration Support } \\
53 \% \\
\text { Lack of Resources } 70 \% \\
\text { Students' evaluation } 28 \% \\
\text { Other } 8 \%\end{array}$ \\
\hline
\end{tabular}


8. What administrative support will you need in order to adopt a new teaching EBT pedagogical approach to your course(s)?

Coordinator/Chair/Dean's

recognition $62 \%$

Given credits for Tenure \&

Promotion \&Evaluation $45 \%$

Appropriate course Scheduling \&

Assignment $64 \%$

Some supplementary salary $36 \%$

Other $9 \%$

The survey showed the majority (75\%) of the faculty members at AAMU are not familiar with the evidence-based teaching pedagogies and haven't used any evidence-based teaching in their courses. However, it is very remarkable that $91 \%$ of faculty members are interested in adopting these pedagogical approaches in their courses in the future. Among those faculty, a majority prefer applying evidence-based teaching in their freshman or sophomore year courses as they realized the first two years are the critical stages to retain and engage students in their discipline areas. Faculty members also raised some concerns such as increased workload, need of administration support and necessary resources, etc. Especially, $62 \%$ of faculty members requested the recognition of the coordinators/chairs/deans for their time and efforts in adopting new teaching strategies; $45 \%$ requested that credits should be given toward their tenure, promotion and faculty evaluation; and $64 \%$ asked for appropriate course schedule and assignments to accommodate their needs when implementing new teaching strategies. It is also noted that about one third of faculty hoped to receive supplementary salary as the compensation for the extra workload. Overall, the faculty survey showed the positive attitude from faculty members toward adopting new teaching pedagogies.

\section{Conclusions and future work}

This pilot study has established the Implementation and Assessment Framework for evidencebased teaching and applied it to three STEM gateway courses successfully at AAMU. The student assessment results indicated the effectiveness of the evidence-based instructional practices, especially in prompting deep thinking and problem solving. In addition, positive feedback has been obtained from the student survey data on the redesigned courses. The SI peerto-peer learning strategies have played an important role in improving the collaborative learning environment outside classrooms at AAMU. Students who participated in the SI sessions demonstrated significant improvement in their exams over their peers who did not participate. This pilot study also confirmed the existing engagement challenges among the freshman and sophomore students in various STEM majors. Future study and implementation of evidencebased teaching will be focused on addressing these challenges.

The faculty survey regarding their awareness, practice and attitude on evidence-based teaching conducted in this project has provided very valuable baseline data to guide the faculty professional development activities at AAMU. The key to improving undergraduate education at AAMU lies in the growth of STEM instructors' abilities to incorporate their content knowledge into effective, evidence-based instruction and to document the efficacy of that instruction. Since most faculty members have relied on the "lecture and listen" format for teaching and learning as their primary pedagogical method, this project will provide a framework and assume a leading 
role in initiating a dialogue about reform and a mechanism to increase faculty buy-in for systemic change in STEM courses instruction. Moreover, this project will develop training workshops and course examples to share with colleagues to ease them accomplish this transition.

The broader impact of this project is twofold. First, data generated through assessment and evaluation will support the theoretical rationale that systematic change in STEM education must include a wide spectrum of stakeholders (administrators, faculty, staff, and students). Secondly, dissemination of the results of this work is expected to provide a model for institutional implementation of evidence-based practices at colleges or universities of similar size and/or student body demographics as AAMU, a land-granted minority serving university.

\section{Acknowledgment}

This project has been supported by the National Science Foundation (NSF) WIDER award\#1347749. The authors greatly appreciate the support and encouragement from the NSF program officer, Dr. Nicole Bennett, the university colleagues and administrators. Special thanks to Ms. Linda Skeete, Program Specialist, Tutorial Assistance Network (TAN) at AAMU for training the SI leaders.

\section{References}

1. Jeffrey J. Kuenzi, Christetine M. Matthew and Bonnie F. Mangan, STEM Education Issues and Legislative Options, Progress in Education, Vol. 14, 161-189(2007).

2. Mitchell Chang, Sylvia Hurtado, Kevin Eagan and Josephine Gasiewski, "Degrees of Success: Batchelor's Degrees Completion Rates among Initial STEM Majors", Higher Education Research Institute at UCLA, (2010).

3. Expanding Underrepresented Minority Participation: America's Science and Technology Talent the crossroad, Committee on Underrepresented Groups and the Expansion of the Science and Engineering Workforce Pipeline, National Academy of Sciences, (2011)

4. http://www.leadered.com/pdf/ Willard R. Daggett, Preparing Students for Their Technological Future, International Center for Leadership in Education (2010),

5. https://www.soils.org/science-policy/sspr/2012-11-21/

6. Chang, M. J., Cerna, O., Han, J., \& Sáenz, V. The contradictory roles of institutional status in retaining underrepresented minorities in biomedical and behavioral science majors. The Review of Higher Education, 31(4), 433-464 (2008).

7. Cohen, D. K. Teaching Practice: Plus ÇA Change. In: Contributions to Educational Change: Perspectives on Research and Practice, National Society for the Study of Education series on Contemporary Issues, edited by P Jackson, pp. 45(1988).

8. http://www.aamu.edu/administrativeoffices/irpsp/InstitutionalResearchandPlanning/FactBook/

9. Armstrong, S. J. \& Fukami, C. (Eds.), Experiential Learning Theory: A Dynamic, Holistic Approach to Management Learning, Education and Development, Handbook of Management Learning, Education and Development. London: Sage Publications (2008)

10. Karl A. Smith, "Inquiry-Based Cooperative Learning, Sigma Xi Conference Proceedings, Resha- ping Undergraduate Science and Engineering Education: Tools for Better Learning, p. 53 (1999)

11. David Hestenes, Modeling Methodology for Physics Teachers, Proceedings of the International Conference on Undergraduate Physics Education(College Park, August (1996) 
12. Gavrin, L, "Using Just-in-Time Teaching in the Physical Sciences" in Just-in-Time Teaching: Across the Disciplines, Across the Academy, Simkins S, and Maier M (Eds.), Sterling, VA: Stylus Publishing. (2010)

13. J. J. Farrell, R. S. Moog, J. N. Spencer "A Guided Inquiry Chemistry Course.". J. Chem. Educ. 76 (4): $570-$ 574 (1999)

14. http://www.learning-theories.com/problem-based-learning-pbl.html

15. Kickmeier-Rust, M.D., Albert, D, Micro-adaptivity: protecting immersion in didactically adaptive digital educational games. Journal of Computer Assisted Learning, 26, 95-105.(2010)

16. http://lincproject.com/cprl2/

17. Fantuzzo, J.W., King, J.A., \& Heller, L.R. Effects of reciprocal peer tutoring on mathematics and school adjustment: A component analysis. Journal of Educational Psychology, 84, 331-339. (1992).

18. Hake. R. R., "Socratic Dialogue Inducing Laboratory Workshop," Proceedings of the UNESCO-ASPEN Workshop on Active Learning in Physics, Univ. of Peradeniya, Sri Lanka, 2-4 Dec. (2002) and http://www.physics.indiana.edu/ hake/

19. E. Etkina and A. Van Heuvelen, Investigative Science Learning Environment: Using th processes of science and cognitive strategies to learn physics, in Proceedings of the 2001 Physics Education Research Conference, Rochester, NY, 17-21, (2001)

20. Barrows, H. S., and Tamblyn, R.N., Problem-Based Learning: An Approach to Medical Education, New York: Springer, 1980

21. Boud, D, and Felleti, G., The Challenge of Problem-Based Learning, New York: St. Martin's Press, 1991.

22. Tiwari, A., Lai, P., So, M., and Yuen, K. 2006. A comparison of the effects of problem-based learning and lecturing on the development of students' critical thinking. Med. Educ. 40, 6, 547-554.

23. Walker, A. and Leary, H. 2009. A problem based learning meta analysis: Differences across problem types, implementation types, disciplines, and assessment levels. Interdiscipl. J. Prob.-Based Learn. 3, 1, 12-43.

24. Strobel, J. and Van Barneveld, A. 2009. When is PBL more effective? A meta-synthesis of metaanalyses comparing PBL to conventional classrooms. Interdiscipl. J. Prob.-Based Learn. 3, 1, 44-58.

25. Carrero, E., Gomar, C., Penzo, W., and Rull, M. 2007. Comparison between lecture-based approach and case/problem-based learning discussion for teaching pre-anaesthetic assessment. Euro. J. Anesthesiol. 24, 12, 1008-1015.

26. Kirschner, P. A., Sweller, J., And Clark, R. E. 2006. Why minimal guidance during instruction does not work: An analysis of the failure of constructivist, discovery, problem-based, experiential, and inquiry-based teaching. Educ. Psychol. 41, 2, 75-86.

27. Formica, SP, Easley, JL, and Spraker, MC, "Transforming common-sense beliefs into Newtonian thinking through Just-In-Time Teaching," Phys. Rev. ST Physics Ed. Research 6, (2010)

28. Lockie, N. M., \& Van Lanen, Impact of the Supplemental Instruction Experience on Science SI Leaders. Journal of Developmental Education, 31(3), 2-4, 6, 8, 10-12, 14 (2008).

29. Bronstein, S. B., Supplemental Instruction: Supporting Persistence in Barrier Courses. Learning Assistance Review, 13(1), 31-45 (2008). 